\title{
Strategi Pembelajaran Seni Musik bagi Siswa Kelas XII SMA Muhammadiyah 2 Yogyakarta dengan Media Audio Visual
}

\author{
Suryati \\ Dosen Jurusan Musik FSP ISI Yogyakarta; Tel. +628179428392; email: atik.jurasik@yahoo.com
}

\begin{abstract}
The SMA Muhammadiyah 2 Yogyakarta is one of the private high schools under Muhammadiyah Foundation, which is located in the center of Yogyakarta city, precisely at Jalan Kapas No. 7 Yogyakarta. In the implementation of teaching and learning activities, this school applies the 2013 national curriculum. The curriculum requires subjects Art culture on the students of the tenth grade, eleven, and twelve. Until now the learning process of the subject of art and culture in the twelve grade classes has been paid less attention by its students because it is considered not important and does not affect the graduation. Because of this reason this research is focused on the cultural arts subject learning strategy, especially for a musical art lesson, for the twelve-grade class students. This research reveals three matters namely; 1) the learning process of art and culture, especially music art, in the 12th class, 2) the application of learning strategy of music art by using audiovisual media, and 3) the impact of applying audio-visual media on music art learning in twelve students in SMA Muhammadiyah 2 Yogyakarta. The method used in this research is qualitative research methods conducted through literature study, field observation, and interviews. The results obtained from this study indicate that, firstly, the process of learning music art in this school begins from planning, implementation, and assessment; Second, the strategy of learning model of music art with audiovisual media used in the learning process apply scientific approach; thirdly, the impact of applying audio-visual media on the learning process is that students can actively participate in lessons, either individually or in groups. In addition, the results of video shows can inspire students in making different musical concept concepts.
\end{abstract}

Keywords: Learning process; musical arts; audio visual

\begin{abstract}
Abstrak
SMA Muhammadiyah 2 Yogyakarta adalah salah satu sekolah swasta di bawah Yayasan Muhammadiyah yang terletak di tengah kota Yogyakarta, tepatnya di Jalan Kapas No. 7 Yogyakarta. Dalam pelaksanaan kegiatan belajarmengajarnya menggunakan kurikulum nasioal 2013. Kurikulum tersebut mewajibkan mata pelajaran Seni budaya pada siswa-siswa kelas aepuluh, sebelas, dan duabelas. Hingga kini proses pembelajaran seni budaya pada kelas duabelas kurang diperhatikan oleh siswasiswanya karena dianggap tidak penting dan tidak mempengaruhi kelulusan. Oleh sebab itu penelitian ini terfokus pada strategi pembelajaran seni budaya, khususnya pelajaran seni musik, untuk siswa-siswa kelas duabelas. Penelitian ini mengungkapkan tiga permasalahan yaitu; 1) proses pembelajaran seni budaya, khususnya seni musik, pada kelas duabelas, 2) penerapan strategi pembelajaran seni musik dengan menggunakan media audio visual, dan 3) dampak penerapan media audio visual pada pembelajaran seni musik pada siswa kelas duabelas di SMA Muhammadiyah 2 Yogyakarta. Metode yang digunakan dalam penelitian ini adalah metode penelitian kualitatif yang dilakukan melalui studi pustaka, observasi lapangan, dan wawancara. Hasil yang didapat dari penelitian ini menunjukkan bahwa, pertama, proses pembelajaran seni musik di sekolah ini diawali dari perencanaan, pelaksanaan dan penilaian; Kedua, strategi model pembelajaran seni musik dengan media audio visual yang digunakan dalam proses pembelajaran menerapkan pendekatan saintifik; ketiga, dampak penerapan media audio visual pada proses pembelajaran ialah bahwa para siswa dapat mengikuti pelajaran dengan aktif, baik secara individu maupun kelompok. Di samping itu hasil dari tayangan video dapat menginspirasi siswa dalam pembuatan konsep penampilan musik yang berbeda.
\end{abstract}

Kata Kunci: Proses Pembelajaran; seni music; audio visual. 


\section{Pengantar}

Pada eraglobalisasi dan informasi teknologi yang semakin meningkat dapat berdampak positif dan negatif bagi semua kalangan baik dari masa anak-anak, remaja, dewasa, hingga lanjut usia. Masa remaja terutama tingkat SMA merupakan masa yang rawan dengan pengaruh lingkungan baik dari internal maupun eksternal, karena masa tersebut masih labil selalu mengikuti arus perkembangan teknologi modern. Hal ini dapat terlihat pada anak-anak remaja sekarang yang selalu aktif menggunakan teknologi terutama alat komunikasi atau Hand Phone (HP) untuk berbagai keperluan. Salah satunya untuk melihat dan mendengarkan lagu-lagu modern seperti; Pop, Jazz, Rock, Reggae dan lain-lain, seperti halnya yang dilakukan siswa SMA Muhammadiyah 2 Yogyakarta. Pada umumnya anak-anak remaja sekarang lebih menyukai musik modern dibandingkan dengan musik Nusantara/ daerah, oleh karena itu musik Nusantara/ daerah semakin tidak diperhatikan dan kurang diminati oleh generasi muda sekarang.

SMA Muhammadiyah 2 Yogyakarta merupakan salah satu sekolah swasta Yayasan Muhammadiyah yang favorit banyak diserbu dari berbagai daerah baik dari Yogyakarta, maupun kota lain, bahkan luar Jawa. Sekolah tersebut terletak di tengah kota Yogyakarta yang berlokasi di Jalan Kapas No.7 Yogyakarta. Oleh karena keadaan siswa SMA Muhammadiyah 2 Yogyakarata yang berasal dari berbagai daerah baik dari Jawa maupun luar Jawa, maka di samping kurang berminat untuk memainkan/ menyanyikan musik Nusantara/ daerah, juga tidak memahami dan mengerti isi lirik lagu-lagu Nusantara/daerah. Sesuai dengan perkembangan musik yang semakin pesat, siswasiswa tersebut terbawa arus lebih menyukai musik-musik modern terutama populer bahkan musik populer manca-negara.
Hal tersebut dapat dilihat pada kondisi kelas disaat proses pembelajaran seni budaya khususnya seni musik yang selalu ramai, saling berbicara dengan sesama teman, mendengarkan musik dengan HP, bahkan keluar masuk kelas pada saat guru menjelaskan dan memberikan contoh tentang musik/lagu-lagu Nusantara/daerah baik dari daerah setempat maupun daerah lain. Namun pada kenyataannya silabus yang tertera di kurikulum 2013 pada mata pelajaran seni budaya, khususnya seni musik untuk kelas $\mathrm{X}$ mempelajari seni tradisi daerah setempat dan musik Daerah lain, kelas XI Musik Nusantara, dan kelas XII musik tradisi mancanegara serta musik modern. Selain itu di dalam silabus juga mepaparkan penampilan musik dari hasil materi pembelajaran, baik secara kelompok maupun individu.

Siswa kelas $X$ siswa SMA Muhammadiyah 2 Yogyakarta dalam proses pembelajaran seni budaya khususnya seni musik di kelas masih dapat dikondisikan dengan baik, karena termasuk siswa baru masa peralihan untuk beradaptasi dan penyesuaian. Berbeda dengan kelas XI yang dianggap masa rawan untuk tingkat SMA, karena sudah merasa kakak kelas yang sudah beradaptasi dan penyesuaian dengan lingkungan sekolah. Lain halnya dengan siswa kelas XII yang sudah banyak kegiatan untuk terfokus menghadapi persiapan Ujian Nasional (UN). Kegiatan tersebut diantaranya; pendalaman materi UN, Try Out, klinik mata pelajaran yang selalu dihadapkan dengan soal-soal, sehingga membuat para siswa merasa jenuh. Oleh karena itu para siswa tersebut kurang berminat dalam mengikuti pelajaran secara serius selain yang dipakai untuk UN. Salah satunya mata pelajaran Seni Sudaya khususnya seni musik yang kurang diminati, jika proses pembelajaran hanya dengan model ceramah, diskusi, imitasi, tidak menarik bagi para siswa, karena dianggap tidak berpengaruh dalam UN. Para siswa tersebut lebih banyak membutuhkan yang ringan-ringan seperti memutar vedio film ataupun 
lagu-lagu untuk refreshing mengendorkan otot agar lebih santai.

Mengatasi situasi dan kondisi keadaan kelas tersebut, peneliti sebagai salah satu pengajar seni budaya di SMA Muhammmadiyah 2 Yogyakarta, maka strategi kegiatan proses pembelajaran Seni Budaya khususnya seni musik berupaya dengan menggunakan media pembelajaran audio visual. Media tersebut digunakan untuk memutar VCD pertunjukan musik. Upaya tersebut diharapkan untuk memotivasi kreativitas siswa dalam berolah musik. Mempelajari Seni Budaya khususnya seni musik adalah upaya untuk dapat mengenali beragam karakter, gaya musik, konsep nada, dan bahasa melalui karya-karya seni musik dengan bentuk dan wujud yang beragam.

Mempelajari Seni Budaya khususnya seni musik adalah upaya untuk dapat mengenali beragam karakter, gaya musik, konsep nada, dan bahasa melalui karyakarya seni musik dengan bentuk dan wujud yang beragam. Tanpa kita sadari bahwa dengan mengenali berbagai ragam lagu-lagu daerah di Indonesia akan menambah wawasan, pengetahuan, dan ikut serta melestarikan seni budaya yang kita miliki. Oleh karena itu untuk meningkatkan minat generasi muda dalam mempelajari dan menyanyikan lagu-lagu daerah khususnya siswa kelas XII SMA Muhammadiyah 2 Yogyakarta, maka diperlukan suatu strategi pembelajaran yang menarik dengan pendekatan media audio visual guna menampilkan karya-karya musik dari berbagai daerah dengan keunikan dan karakter yang berbeda.

Berbagai ragam corak seni budaya mencerminkan kekayaan budaya yang semestinya dapat menimbulkan rasa keingintahuan yang terus menerus. Keadaan itu merupakan sebuah iklim yang dinamis di kalangan keilmuan karena menunjukkan potensi kerja yang selalu dipenuhi dengan energi positif untuk mendalami karya-karya asli milik bangsa sendiri yang sudah selayakna kita hargai tinggi. Pada saat sebagian elemen bangsa besar ini terbuai dengan arus globalisasi sebagai efek dari modernisasi kita dihadapkan pada pilihan untuk dengan kerendahan hati menjadikan budaya dan seni bangsa sendiri agar tetap menjadi tuan di negeri sendiri. Hal ini menjadi perhatian tersendiri karena kita menuntut diri kita sendiri untuk dapat menjaga dan melestarikan karya seni budaya bangsa sendiri dengan penuh kesungguhan serta keyakinan bahwa pada saatnya bangsa ini tak akan terkikis nasionalisme serta identitasnya bukan karena terlalu resisten terhadap perkembangan dunia baru tetapi karena kita memang memahami dan mencintai hasil karya asli bangsa dan menjaganya dengan kesungguhan hati agar jangan sampai hilang yang menyebabkan kita mengalami penyesalan panjang.

Terkait dengan hal tersebut maka mengenal, memahami, menjaga dan mempertahankan eksistensi karya seni budaya khususnya musik daerah merupakan perjuangan yang setara dengan perjuangan mempertahankan kemerdekaan khususnya di bidang seni budaya terutama seni musik. Sasaran yang kita akan capai ialah tampilnya identitas daerah-daerah yang satu dan lainnya membentuk mozaik besar menjadi identitas bangsa dan melihatnya dari kejauhan akan merasakan sebuah kebanggaan tersendiri. Hal ini menjadi keinginan semua, melihat bangsa besar ini memiliki identitas yang jelas dan mandiri tanpa tercampuri dengan hal-hal yang lain. Lagu-lagu daerah sebagai salah satu bentuk karya seni musik daerah merupakan objek yang menyenangkan untuk ditelaah baik dari sisi musiknya sendiri maupun makna teks lagu yang mestinya berisi kebijakan-kebijakan lokal yang pantas kita ketahui.

Melihat kenyataan bahwa generasi muda khususnya siswa kelas XII SMA Muhammadiyah 2 Yogyakarta sebagai representasi generasi yang perlu mempelajari seni budaya khususnya seni musik untuk selalu dimotivasi agar proses penanaman rasa cinta 
pada akar budaya dan seni bangsa sendiri dapat berlangsung secara baik, maka hal ini menarik untuk diteliti agar dapat mengungkapkan beberapa permasalahan yang ada. Adapun beberapa permasalahan tersebut diantaranya; untuk mengetahui proses pembelajaran seni musik pada siswa kelas XII SMA Muhammadiyah 2 Yogyakarta, strategi pembelajaran seni musik dengan media audio visual, dan dampak penerapan media audio visual dalam proses pembelajaran seni musik pada siswa kelas XII SMA Muhammadiyah 2 Yogyakarta.

\section{Pembahasan}

\section{Metode penelitian}

Penelitian ini menggunakan deskriptif analisis dengan memanfaatkan data kualitatif. Dalam penelitian kualitatif seorang peneliti dituntut harus mampu mengeksplanasikan semua bagian yang dipercaya dari sumber informasi yang diketahuinya serta tidak menimbulkan kontradiksi dengan interpretasi yang disajikan (R.M. Soedarsono, 1999). Penelitian ini di-lakukan melalui beberapa tahap yang diawali dengan studi pustaka untuk melihat penelitian terdahulu dan keaslian dari topik yang diteliti, serta mencari referensi dalam mendukung penulisan penelitian. Selanjutnya dilakukan studi lapangan dengan observasi, wawancara, dan dokumentasi, adapun secara rinci dapat teruraikan sebagai berikut.

\section{a. Bahan atau Materi}

Objek penelitian adalah penerapan audio visual dalam proses pembelajaran lagu-lagu daerah dan modern di SMA Muhammadiyah 2 Yogyakarta. Peneliti mengambil sampel dari siswa kelas XII MIA 5.

\section{b. Alat Bantu}

Alat untuk membantu dalam mengungkapkan permasalahan pada penelitian ini adalah alat tulis, dokumentasi baik untuk perekaman ataupun foto.

\section{c. Jalan Penelitian}

Penelitian ini menyelusuri dari permasalahan yang dihadapi oleh guru dalam proses pembelajaran seni budaya khususnya seni musik dengan media audio visual di kelas XII SMA Muhammadiyah 2 Yogyakarta dan dampak penerapan media audio visual pada siswa kelas XII MIA 5. Pengamatan dilakukan secara langsung di lapangan pada waktu kegiatan belajar mengajar seni budaya khususnya seni musik.

\section{d. Variabel}

Variabel yang akan dipelajari diantaranya: keadaan siswa kelas XII MIA5, tujuan penerapan media audio visual pertunjukan musik kreasi dengan lagu-lagu daerah, dan dampak penerapan audio visual pertunjukan musik kreasi dengan lagu-lagu daerah terhadap siswa kelas XII MIA5 SMA Muhammadiyah 2 Yogyakarta.

\section{e. Prosedur Pelaksanaan}

Penelitian ini secara kronologis dapat dilakukan melalui beberapa tahapan yaitu pengumpulan data melalui studi pustaka dan studi lapangan (observasi dan wawancara), analisis data, serta pembuatan pelaporan. Penelitian studi lapangan dilakukan untuk mendapatkan data-data tentang objek yang diteliti melalui observasi, wawancara dengan mengajukan pertanyaanpertanyaan kepada nara sumber atau informan, dan perekaman (Moleong, 1999). Observasi ditujukan kepada guru seni budaya dan siswa kelas XII pada waktu kegiatan belajar mengajar secara langsung di SMA Muhammadiyah 2 Yogyakarta. Selanjutnya untuk memperoleh data-data yang tidak dapat dilakukan melelui observasi, maka di-lakukan wawancara langsung kepada guru dan perwakilan siswa kelas XII. Kemudian untuk mendukung kepentingan dalam pembahasan dilakukan perekaman secara audio visual pada pelaksanaan 
kegiatan belajar mengajar dibantu oleh Gilang Abdi Pamungkas salah satu mahasiswa minat utama Musik Pendidikan, Jurusan Musik, Fakultas Seni Pertunjukan ISI Yogyakarta.

\section{f. Analisis Data}

Adapun data-data yang terkumpul dari hasil studi lapangan dan studi pustaka dianalisis secara kualitatif. Data tersebut dikelompokan sesuai dengan permasalahan yang dihadapi. Selanjutnya data tersebut disusun dalam kategori-kategori tertentu untuk mengacu pada pokok-pokok bahasan yang teleh ditentukan dalam penelitian.

\section{Pembelajaran Seni Musik Kelas XII SMA Muhammadiyah II Yogyakarta}

SMA Muhammadiyah 2 Yogyakarta merupakan salah satu sekolah swasta Yayasan Muhammadiyah yang terletak di tengah kota Yogyakarta berlokasi di Jalan Kapas No.7 Yogyakarta. Sekolah tersebut memiliki 27 kelas paralel dengan perincian kelas $X$ terdiri dari 9 kelas yaitu X MIA1-5 dan X IIS1-4, kelas XI terdiri dari 9 kelas yaitu XI MIA1-5 dan XI IIS1-4, kelas XII MIA1-5 dan XII IIS1-4, setiap kelasnya sekitar 30-37 siswa. Dalam pelaksanaan Kegiatan Belajar Mengajar (KBM) yang dilakukan di SMA tersebut menggunakan Kurikulum 2013. Seni budaya merupakan salah satu mata pelajaran yang wajib diberikan di kelas X, XI, XII, baik program MIA ataupun IIS. Proses pembelajaran seni budaya pada siswa kelas XII SMA Muhammadiyah 2 Yogyakarta dilakukan melalui beberapa tahap, karena mata pelajaran seni budaya meliputi 4 cabang seni sesuai yang tertera di Kurikulum 2013, yaitu; seni rupa, musik, tari dan teater. Walaupun banyak sekolah yang sudah tidak menggunakan Kurikulum 2013, akan tetapi SMA Muhammadiyah 2 Yogyakarta masih tetap menggukan kurikulum 2013. Setiap cabang seni tersebut dialokasikan 4 kali pertemuan dengan 2 jam pelajaran x 45 menit, seperti yang tertera di dalam silabus mata pelajaran seni budaya SMA. Dengan demikian setiap semester 4 cabang seni tersebut memerlukan 16 pertemuan dengan 2 jam pelajaran

Proses pembelajaran seni budaya pada semester gasal tahap pertama diberikan cabang seni rupa dengan 4 kompetensi dasar atau materi pokok sesuai yaitu: mengevaluasi karya seni rupa dua dimensi, berkreasi karya seni dua dimensi, mengevaluasi karya seni tiga dimensi dan berkreasi karya seni rupa tiga dimensi. Tahap kedua setelah selesai materi seni rupa kemudian diberikan seni musik dengan 4 kompetensi dasar atau materi pokok yaitu; memahami karya musik kreasi, menganalisis karya musik kreasi, membuat konsep karya musik kreatif dan menampilkan musik. Selanjutnya tahap ketiga cabang seni tari dengan 4 kompetensi dasar atau materi pokok yaitu; mengevaluasi konsep tari kreasi, menganalisis gerak tari, mengkreasi gerak tari dan menampilkan tari kreasi. Kemudian Tahap terakhir seni teater dengan 4 kompetensi atau materi pokok yaitu; mengevaluasi konsep naskah drama, membuat konsep naskah drama, mengkreasi karya teater, menampilkan karya teater. Keempat cabang tersebut masing-masing memerlukan 4 pertemuan untuk menyampaikan materi dan 1 pertemuan untuk ulangan harian.

Meskipun mata pelajaran seni budaya terdiri dari 4 cabang seni, namun penelitian ini hanya terfokus pada proses pembelajaran seni musik. Dalam proses pembelajaran seni budaya khususnya seni musik mengambil 1 materi pokok dari keempat kompetensi dasar tersebut. Proses pembelajaran seni musik dimulai dengan memahami karya musik kreasi secara mendalam, baik dari segi jenis, konsep, maupun bentuknya. Setelah memahami karya musik kreasi, kemudian untuk pertemuan berikutnya menganalisis karya musik kreasi berdasarkan jenis dan fungsinya. Langkah selanjutnya membuat konsep karya musik kreasi secara kelompok dan klasikal kemudian 
menampilkan hasil karya musik kreasi dalam bentuk pertunjukan seni kreatif secara kelompok.

Proses pembelajaran merupakan suatu proses yang mengandung serangkaian kegiatan mulai dari perencanaan, pelaksanaan hingga penilaian. Oleh karena itu proses pembelajaran seni budaya khususnya seni musik yang dilakukan oleh guru di SMA Muhammadiyah 2 Yogyakarta, diawali dengan perencanaan Kegiatan Belajar Mengajar (KBM) yaitu membuat perangkat pembelajaran dalam 1 semester yang berisi analisis minggu efektif, program tahunan, program smester, silabus dan RPP (Rencana Pelaksanaan Pembelajaran). Setelah membuat perencanaan kemudian melaksanakan proses pembelajaran sesuai rencana program yang disusun. Selain melaksanakan proses pembelajaran juga dilakukan penilaian baik nilai sikap, pengetahuan, maupun ketrampilan baik secara kelompok maupun individu yang sudah ditentukan standart dan panduan penilaiannya oleh sekolah, 2005: 206).

\section{Strategi Model Pembelajaran Seni Musik dengan Media Audio-Visual}

Model pembelajaran adalah sebuah kerangka konseptual yang menggambarkan prosedur yang sistematis dari awal sampai akhir yang disajikan secara khas oleh guru untuk mencapai tujuan pembelajaran. Model pembelajaran dapat berfungsi sebagai pedoman bagi para perancang pembelajaran dan para pengajar dalam merencanakan serta melaksanakan aktivitas pembelajaran. Oleh sebab itu model pembelajaran merupakan kerangka atau konsep dari penerapan suatu pendekatan, metode, dan teknik dalam proses pembelajaran.

Berdasarkan Permendikbud Nomor 65 Tahun 2013 tentang Standar Proses, model pembelajaran yang diutamakan dalam implementasi Kurikulum 2013 diantaranya;

a. Model pembelajaran Inkuiri (Inquiry Based Learning) yaitu proses belajar melalui penggunaan cara-cara bertanya, aktivitas problem solving, dan berpikir kritis. Contoh pembelajarannya kelas dibagi ke dalam kelompok-kelompok kecil, kemudian setiap kelompok diberi sebuah pertanyaan atau permasalahan yang akan mengarahkan semua anggota kelompok bekerja bersama mengembangkan proyek berdasarkan pertanyaan tersebut untuk menemukan jawabannya.

b. Model pembelajaran Discovery (Discovery learning) yaitu proses embelajaran yang terjadi apabila siswa tidak disajikan dengan pelajaran dalam bentuk finalnya, tetapi diharapkan mengorganisasi sendiri. Pada kegiatan ini guru memberikan stimulan, dapat berupa bacaan, atau gambar, atau situasi, sesuai dengan materi pembelajaran/ topik/ tema yang akan dibahas, sehingga siswa mendapat pengalaman belajar mengamati pengetahuan konseptual melalui kegiatan membaca, mengamati situasi atau melihat gambar.

c. Model pembelajaran berbasis projek (Project based learning), yaitu metode mengajar dengan fokus pemecahan masalah yang nyata, kerja kelompok, umpan balik, diskusi, dan membuat laporan akhir. Dengan demikian siswa didorong untuk lebih aktif terlibat dalam materi pelajaran dan mengembangkan keterampilan berpikir kritis.

d. Model pembelajaran berbasis permasalahan (Problem Based Learning) yaitu model pembelajaran yang menggunakan proyek/kegiatan sebagai media. Guru menugaskan siswa untuk melakukan eksplorasi, penilaian, interpretasi, sintesis, dan informasi untuk menghasilkan berbagai bentuk hasil belajar. Proses pembelajaran seni budaya diperlukan 
suatu model pembelajaran yang sesuai dan tepat, agar materi dapat tersampaikan dengan baik dan menarik.

Model pembelajaran mata pelajaran seni budaya khususnya seni musik kelas XII SMA Muhammadiyah 2 Yogyakarta menggunakan pendekatan saintifik meliputi lima langkah yang disebut dengan $5 \mathrm{M}$, yaitu; mengamati, menanya, mengeksplorasi, mengasosiasi, mengkomunikasikan. Strategi model pembelajaran seni musik dengan media audio visual pada materi pokok musik kreasi, diputarkan video pertunjukan musik kreasi. Para siswa dibagi menjadi beberapa kelompok diminta untuk mengamati, mengumpulkan informasi atau data, kemudian dianalisis dan didikusikan secara kelompok kemudian hasil temuannya ditulis dan dipresentasikan di depan kelas.

Langkah-langkah penerapan model pembelajaran dengan pendekatan saintifik adalah sebagai berikut.

a. Mengamati; kegiatan siswa mengidentifikasi melalui indera penglihatan mengamati suatu objek dari tayangan video pertunjukan musik kreasi, yang digunakan untuk mengidentifikasi konsep, teknik, dan prosedur Penampilan.

b. Menanya; kegiatan siswa membuat pertanyaan secara individu atau kelompok tentang apa yang belum diketahui dalam tayangan video pertunjukan musik kreasi, tentang konsep, teknik dan prosedur penampilan musik kreasi.

c. Mengeksplorasi; kegiatan siswa mencari dan mengumpulkan informasi dari tayangan video pertunjukan musik kreasi mengenai konsep, teknik dan prosedur penampilan sebagai bahan untuk dianalisis dan disimpulkan.

d. Mengasosiasi; kegiatan siswa mengolah data dan mempresentasikan hasil temuan tayangan video pertunjukan musik kreasi mengenai konsep, teknik dan prosedur penampilan.

e. Mengkomunikasikan; yaitu kegiatan siswa mendeskripsikan dan menyampaikan hasil temuannya dari kegiatan mengamati, menanya, mengumpulkan dan mengolah data, mengasosiasi, serta menganalisis dari tayangan video pertunjukan musik kreasi baik secara lisan maupun tulisan. Guru bersama siswa kelompok lain memberikan tanggapan atau evaluasi hasil presntasi secara kelompok.

Strategi pembelajaran dengan media audio visual untuk memutarkan pertunjukan musik baik musik tradisi maupun modern ini dilakukan agar siswa lebih terfokus, terinspiratif dan bisa lebih banyak dalam melihat tayangan video pertunjukan musik, dengan tidak harus melihat secara langsung (live). Hal ini di samping tidak harus mengeluarkan biaya untuk melihat sebuah pertunjukan musik secara live juga siswa lebih leluasa dalam melihat berbagai macam bentuk tayangan pertunjukan. Berbagai tayangan tersebut dapat digunakan sebagai referensi dalam membuat konsep penampilan musik kreasi secara kelompok, karema setiap akhir semester diadakan penampilan musik sebagai bentuk evaluasi hasil pembelajaran seni budaya khususnya seni musik.

\section{Dampak Strategi Model Pembelajaran dengan Media Audio-Visual}

Dampak strategi pembelajaran dengan media Audio Visual dalam proses pembelajaran seni budaya khususnya seni musik, yang paling terlihat adalah para siswa kelas XII SMA Muhammadiyah 2 Yogyakarta 
dalam mengikuti pelajaran dapat terkondisikan dengan tenang dan baik. Selain itu juga siswa dapat terfokus karena harus mengamati tayangan video sebuah pertunjukan musik kreasi yang akan didiskusikan secara kelompok. Selanjutnya siswa tersebut secara kelompok aktif mendiskusikan dan mempersiapkan hasil dari diskusi yang akan disampaikan baik secara lisan maupun tulisan untuk dipresentasikan di depan kelas.

Di samping kelas dapat terkondisikan dengan baik, juga setelah melihat tayangan video pertunjukan musik kreasi, para siswa terinspirasi untuk membuat ide dan gagasan, konsep, teknik, serta prosedur dalam penampilan musik kreasi untuk penilaian pada akhir semester. Hal ini dilakukan karena penilaian seni budaya khususnya seni musik selain nilai sikap, pengetahuan juga ketrampilan. Penilaian ketrampilan seni musik dilakukan dengan menampilkan dari hasil karya kreativitas siswa secara kelompok yang dipertunjukan disetiap akhir semester.

Dampak yang lebih nyata terlihat ketika para siswa menampilkan hasil kreativitas pertunjukan seni kreatif dalam penilaian ketrampilan pada akhir semester, masingmasing kelas menunjukan kelebihannya dan ada kecenderungan untuk bersaing ingin menampilkan yang terbaik. Setelah melihat dan mengamati tayangan video pertunjukan musik kreatif, secara garis besar para siswa kelas XII yang terdiri dari 9 kelas dalam penampilanya banyak mengkreasikan lagu-lagu daerah yang dilengkapi gerakan tari sekaligus sebagai koreogafinya.

Konsep aransemen musik pada penampilan akhir semester pada umumnya para siswa banyak menggunakan ritmis yang sederhana dengan instrumen perkusi seperti galon aqua, cajon dan lain-lain, sedangkan untuk aransemen vokal masih banyak yang unisono (satu suara), walaupun sebagaian sudah menggunakan dua suara dengan harmoni yang sederhana tetapi tetap menarik.."

\section{Penutup}

Berdasarkan uraian hasil penelitian yang dicapai, maka dapat disimpulkan bahwa proses pembelajaran seni budaya khususnya seni musik kelas XII SMA Muhammadiyah 2 Yogyakarta melalui beberapa tahap. Proses pembelajaran seni musik diawali dengan perencanaan Kegiatan Belajar Mengajar (KBM) yaitu membuat perangkat pembelajaran dalam 1 semester yang berisi analisis minggu efektif, program tahunan, program smester, silabus dan RPP (Rencana Pelaksanaan Pembelajaran). Setelah membuat perencanaan kemudian melaksanakan proses pembelajaran sesuai rencana program yang disusun. Selain melaksanakan proses pembelajaran juga dilakukan penilaian baik nilai sikap, pengetahuan, maupun ketrampilan.

Model pembelajaran merupakan kerangka atau konsep dari penerapan suatu pendekatan, metode, dan teknik dalam proses pembelajaran. Model pembelajaran yang digunakan mengacu pada kurikulum 2013. Oleh karena itu materi pelajaran dapat tersampaikan dengan baik diperlukan suatu pendekatan dan metode yang sesuai dan tepat. Model pembelajaran mata pelajaran seni budaya khususnya seni musik kelas XII SMA Muhammadiyah 2 Yogyakarta menerapkan pendekatan saintifik meliputi lima langkah yaitu; mengamati, menanya, mengumpulkan data, mengasosiakan dan mengkomunikasikan. Strategi pembelajaran seni musik dengan media audio visual dapat memutarkan berbagai pertunjukan musik tanpa harus mengeluarkan biaya dalam melihat sebuah pertunjukan musik secara live juga siswa lebih leluasa dalam melihat berbagai macam bentuk tayangan pertunjukan.

Dampak penerapan model pembelajaran dengan media Audio Visual dalam proses pembelajaran seni budaya khususnya seni musik kelas XII SMA Muhammadiyah 2 Yogyakarta, maka para siswa dapat belajar dengan tertib. Situasi proses pembelajaran di kelas dapat hidup, setelah mengamati, 
kemudian menanya, mengumpulkan data, mengasosiasikan dan menyimpulkan yang diakhiri dengan mengkomunikasikan secara kelompok di depan kelas. Selain itu setelah melihat dan mengamati tayangan video pertunjukan musik kreasi dapat menginspirasikan ide dan gagasan para siswa untuk membuat konsep penampilan musik kreasi yang akan digunakan dalam penilaian ketrampilan.

\section{Catatan:}

Paper ini adalah hasil penelitian Dibiayai oleh DIPA ISI Yogyakarta tahun 2016, Nomor: DIPA-042.01.2.400980/2016 tanggal 7 Desember 2015. Berdasarkan SK Rektor Nomor: 213/KEP/2016 tanggal 10 Juni 201. Sesuai Surat Perjanjian Pelaksanaan Kegiatan Nomor: 4124/IT4/LT/2016 tanggal 13 Juni 2016.

\section{Referensi}

Amri, S dan Akhmad. K. L. 2010. Kontruksi Pengembangan Pembelajaran. Jakarta: Prestasi Pustaka.

Djamarah, Syaiful Bahri. 2000. Guru dan Anak Didik Dalam Interaksi Edukatif. Jakarta: PT. Rineka Cipta.
Haryono, Timbul. 2009. Peran Masyarakat Intelektual dalam Penyelamatan dan Pelestarian Wariran Budaya Lokal. Yogyakarta: Universitas Gadjah Mada.

Moleong, Lexy J. 1999. Metodologi Penelitian Kualitatif. Bandung: PT. Rosda Karya.

Nur Syam. 2008. Tantangan Baru Multikulturalisme di Indonesia, Kanisius, Yogyakarta.

Purwasito, Andrik. 2003. Komunikasi Multikultural. Surakarta: Universitas Muhammadiyah.

Sardiman A.M, 2005. Interaksi \& Motivasi Belajar Mengajar. Jakarta: PT. Raja Grafindo Persada.

Soedarsono, R.M. 1999. Metodologi Penelitian Seni Pertunjukan dan Seni Rupa. Bandung: MSPI.

Suyudi. 2013. Strategi Pembelajaran Pendidikan Karakter. Bandung: PT Ramaja Rosdakarya.

Trianto. 2009. Mendesain Model Pembelajaran Inovatif-Progresif. Jakarta: Prestasi Pustaka.

Zamroni, 2000. Paradigma Pendidikan Masa depan. Yogyakarta: BIGRAF Publishing. 